\title{
Determinants of Mentoring and its Significance in Career Success: A Brief Literature Review
}

\author{
Mahmoud Kamal Abouraia \\ Hamdan Bin Mohammed Smart University \\ PO Box 71400, Dubai Academic City, Dubai, United Arab Emirates \\ E-mail: mkas.abou200@gmail.com \\ Lamis Riyad Mohamed Albdour \\ Department of Human Resources, City University College of Ajman \\ Khalifa Bin Zayed Road, College Street, Al Nuimia, Ajman, United Arab Emirates
}

Received: Aug. 10, 2017 Accepted: Aug. 28, 2017 Online published: Oct. 16, 2017

doi:10.5296/ijhrs.v7i4.12002ＵRL: https://doi.org/10.5296/ ijhrs.v7i4.12002

\begin{abstract}
Most of us commonly use our ability and wisdom to assist and guide others. However, this kind of assistance is not just beneficial for individuals equally. For instance, it will be time pressure to guide colleagues to boost their capability and progress their course that will lead to more disadvantageous to the operation. Mentoring is a kind of auxiliary and casual administrative conversation that is very compelling in career growth. Workers and administrators in all kind of organization require grasping this fact and its affiliation in achieving their goals so that they can professionally promote their employees and attain outstanding victory in the workplace. It is likewise an instrument that organizations can take advantage of, to help them nourish and flourish their employee. As organizations endeavor to keep hard earned knowledge and wisdom, they are embracing the mentoring method as a mode of social knowledge administration. This subject has been explored and examined beyond much development for the past years. And organizations are witnessing breathtaking progress in performance, competence and, of course, the transmission of corporate intelligence and leadership skills. In this article we incorporate the dominant frame of mentoring literature with a decade of observational analysis by the authors using a range of case of the working community and seeking at the benefits of mentoring on career success with the mentor and mentee as well.
\end{abstract}

Keywords: Career success, Mentoring, Social knowledge 


\section{Introduction}

Mentoring is a substantial phase of administrative specialization and career advancement. Considering this is fairly definite and spontaneous intelligence method with such an impressive result, it is crucial to gain more about what organizations and employees can do to nurture and improve their mentoring privileges (Bahniuk and Hill, 1998). Through generations, conventional mentoring is portraying an eminent function in giving the guidance needed from seniors to juniors to achieve their goal of succeeding in their career. With this growing publicity, mentoring is one of the eminently explored subjects nowadays. It even has attracted an enormous number of attentions in scholastic as well as expert society. Research indicates that personnel with a mentor will more probably lead to have work advancement, obtain higher salary, and establish high work achievement than personnel without a mentor (Dreher and Ash, 1990; Scandura, 1993; Scandura and Schriesheim, 1994; Turban and Dougherty, 1994; Ragins et al., 2000). As an example, a meta-analysis established that mentoring method was correlated with subjective conclusion such as career fulfillment and assumption for career growth (Allen et al., 2004).

Mentoring has been seen from such alternate points of view as administration, correspondence, training and vocation improvement. The emphasis here is on mentoring in the business environment and it's one of a kind and intense impact on profession achievement. Concentrating on mentoring inside the political point of view of an association adds to the business writing. Currently, improvement of a political viewpoint in hierarchical correspondence hypothesis has propelled a key perspective of correspondence showing how different strategies and practices can be utilized to finish individual objectives and vocation achievement (Bahniuk and Hill, 1998). To precipitate mentoring analyst and anticipate more widely relating to the probable part of mentoring in protégés development and to boost mentoring hypothesis, an extensive multi-corrective meta-analysis was administered. Our fundamental purpose was to answer the question, "How significant is mentoring to one's career success?" This is a substantial question because the prominent media makes resilient demands about the significant of mentoring while both public and private funds are utilized to reinforce numerous types of mentoring drive (Rhodes, 2005).

\section{Overview of Mentorship Study}

Mentoring is a connection between two people in light of a common craving for improvement towards professional objectives and destinations. The relationship is a non-broadcasting one and substituting zero of the hierarchical structures set up. It is an addition to different types of guidance, like formative assignments, classroom leadership, and work preparing and coaching. In a mentoring relationship, the two people are alluded to as the "mentor" and the "mentee" (the individual being mentored). It gives advancement chances to both accomplices. Customary mentoring concentrates on creating junior representatives (mentees) by matching them with more experienced and regularly ranking staff (coaches) for a while. So basically it signifies the relationship of seniors' aides, advices or directing the less experienced juniors in view of the taking after components. Despite the structure mentoring takes, it encourages the sharing of information, ability, aptitudes, bits of knowledge and encounters through exchange 
and cooperative learning. It is objective situated and advances proficient and self-improvement amongst members.

\subsection{The Objective of Mentorship}

The objective of the mentoring system is to build up a trusting association with responsibility and obligation from the mentor and protégé. The center goal of mentoring is to pull in, persuade, create and hold profitable ability while expanding efficiency by utilizing a continuum of consideration making a developing and sound relationship between the mentor and the protégé. This is further explained as takes after:

- To prepare and create current representatives to improve efficiency

- To support individual and expert development and expansion work fulfillment

- To comprehend and react to the variety quality needs of the workforce

- To source new representatives and help them get to know the association and adapted to their occupation

- To distinguish and create workers with promising talent to fulfill essential administrative functions.

\subsection{Types of Mentoring}

A mentoring connection between a mentor and mentee can be sorted in two types either formal or informal in nature (Buell, 2004). First, formal or career improvement is the formal mentoring programs predominantly concentrates on preparing, worker socialization, individual and expert improvement, sponsorship or deceivability/introduction than on, inward arranged psychosocial formative capacities. A mentor and mentee are doled out to be as one through hierarchical task of help (Ragins et al., 2000). Second, informal mentoring or psychosocial capacities is the past structure where the guide chooses a mentee whom he can relate with, rises instinctively and suddenly due to a common fondness between a mentor and mentee, more often than not without help from the association and the tutor frames the good example for the mentee. At the point when completed viable, mentoring can possibly enhance further absolute influential results and be an existence modifying association with significant shared learning, advancement and development opportunities (Ragins and Kram, 2007; Hoffman and Loughead, 2016).

\subsection{Mentoring Functions}

Additional exploration stream has attempted to distinguish the distinctive capacities or parts of mentoring. As these capacities and functions modifies over the fields, there is no accord on what includes mentoring capacities. In any case, most studies concur that coaching is multi-dimensional. Few studies have recognized two measurements of mentoring: the career improvement function which help the mentee take in the ropes and get ready for profession headway and the psychosocial support function which assist the mentee build up a feeling of expertise and certainty of character (Cho et al., 2011; Haggard et al., 2011; Lankaua et al., 2006; Scandura, 1992; Viator, 2001; Reid et al., 2008). The vocation advancement capacity 
has been the most frequently talked about. This part of mentoring predominantly includes a mentor's backing for a mentee to take in his/her own employment details, to improve work demonstrable skill, and to take care of occupation related issues (Allen and Eby, 2003; Ayres, 2006; Aryee et al., 1999; Patwardhan and Venkatachalam, 2012; Scandura, 1992; Viator, 2001).

Previous study identified that mentoring was extremely useful for the professional success, as it empowered data sharing among commanded representatives in workplace (Patwardhan and Venkatachalam, 2012). These researchers reasoned that mentoring is a viable vehicle for empowering singular employment/professional success, like, advancement to a superior position or exchange to a superior organization (Leavitt, 2011). Another study established that correspondence and systems administration with other individual was one of the profession aptitude measurements empowered by mentoring. The vocation advancement capacity permits mentees to enhance their working execution and achieve their vocation objectives. Nevertheless, it tends to over stress "aspiration for achievement" or "advantage for achievement," and urges mentees to forcefully exploit mentoring (Allen et al., 2008; Noe, 1988; Viator, 2001). This implies as a general rule, a mentee may figure out how to delight or significantly compliment a prevalent, how to effectively finish workloads utilizing momentary convenient measures, or how to be rapidly advanced.

These issues above drove scholastics to contemplate the social and mental elements of mentoring. The psychosocial support function has been generally less referenced in the mentoring writing than the career-development function. In any case, another imperative function of mentoring is to assist mentees settle their mental connection to an association or organization, and modify themselves to their hierarchical surroundings (Allen et al., 2008; Kram, 1985). Such assistance occurs as mentees offer individual stresses or worries with their mentors and build an enthusiastic relationship (Lankaua et al., 2006). This function of mentoring can be clarified through leader-member exchange hypothesis (LMX), in which great LMX connections are described by appreciation and trust. Such kind of connections is cultivated by close mentoring (Graen and Uhl-Bien, 1995; Kim et al., 2010; Schyns and Croon, 2006). Accordingly, this function is advanced through different variety of methodologies that include a mentor's personal support/directing, the arrangement of kinships, or the combination of the mentees' mental soundness in their hierarchical group (Cho et al., 2011; Eby et al., 2000; Fagenson, 1992; Mullen and Noe, 1999, Kim et al., 2015).

Table 1. Mentoring Functions and its Advantages to Mentor \& Mentees

\begin{tabular}{|c|c|c|c|}
\hline FUNCTION & DEFINITION & $\begin{array}{l}\text { MENTEE } \\
\text { ADVANTAGES }\end{array}$ & $\begin{array}{l}\text { MENTOR } \\
\text { ADVANTAGES }\end{array}$ \\
\hline \multicolumn{4}{|l|}{ CAREER } \\
\hline $\begin{array}{l}\text { Challenging } \\
\text { Assignments }\end{array}$ & $\begin{array}{l}\text { Doles out mentee strenuous } \\
\text { work, bolstered with } \\
\text { preparing and progressing } \\
\text { efficiency criticism }\end{array}$ & $\begin{array}{l}\text { Vital specialized and } \\
\text { administrative abilities } \\
\text { created through work, } \\
\text { upheld through learning } \\
\text { troublesome undertakings }\end{array}$ & $\begin{array}{l}\text { Can mitigate senior } \\
\text { supervisor of errands; gets } \\
\text { support that permits } \\
\text { consideration regarding } \\
\text { different assignments }\end{array}$ \\
\hline
\end{tabular}




\begin{tabular}{|c|c|c|c|}
\hline Protection & $\begin{array}{l}\text { Safeguards from inopportune } \\
\text { or possibly harming contact } \\
\text { with senior chiefs by } \\
\text { assuming acknowledgment } \\
\text { or fault in disputable } \\
\text { circumstances or interceding } \\
\text { when mentee is badly } \\
\text { prepared to accomplish } \\
\text { palatable determination }\end{array}$ & $\begin{array}{l}\text { Decreases hazard, yet can } \\
\text { be steady or covering; } \\
\text { additionally may } \\
\text { counteract introduction } \\
\text { that could upgrade } \\
\text { notoriety; equalization can } \\
\text { be more hard to discover in } \\
\text { cross-sexual orientation } \\
\text { connections }\end{array}$ & $\begin{array}{l}\text { Affirms capacity to } \\
\text { decidedly intercede and } \\
\text { utilize clout; } \\
\text { notwithstanding, can act } \\
\text { naturally serving if used to } \\
\text { assemble own notoriety at } \\
\text { cost of mentee's } \\
\text { development }\end{array}$ \\
\hline Coaching & $\begin{array}{l}\text { Traces particular techniques } \\
\text { for fulfilling work targets } \\
\text { and accomplishing vocation } \\
\text { goals; offers comprehension } \\
\text { of vital issues and players }\end{array}$ & $\begin{array}{l}\text { Gives casual information } \\
\text { of association, expands } \\
\text { viewpoint, and improves } \\
\text { capacity to explore in } \\
\text { association }\end{array}$ & $\begin{array}{l}\text { Going on learning affirms } \\
\text { the estimation of } \\
\text { experience; feels } \\
\text { successful; guarantees that } \\
\text { individual perspective } \\
\text { without bounds is endured }\end{array}$ \\
\hline
\end{tabular}

\begin{tabular}{|c|c|c|c|}
\hline Sponsorship & $\begin{array}{l}\text { Effectively designates junior } \\
\text { associate for alluring parallel } \\
\text { moves and advancements }\end{array}$ & $\begin{array}{l}\text { Assembles notoriety and } \\
\text { achieve openings for work }\end{array}$ & $\begin{array}{l}\text { Seen as having great } \\
\text { intuition, recognized for } \\
\text { discovering and } \\
\text { establishing ability; can } \\
\text { improve or harm coach's } \\
\text { notoriety, contingent upon } \\
\text { how mentee performs }\end{array}$ \\
\hline
\end{tabular}

\begin{tabular}{lll}
\hline Exposure/Visibility & $\begin{array}{l}\text { Provides subordinate partner } \\
\text { obligations that take into }\end{array}$ & $\begin{array}{l}\text { Finds out about different } \\
\text { parts of the association and } \\
\text { consideration the }\end{array}$ \\
$\begin{array}{ll}\text { advancement of associations } \\
\text { with essential knowledge }\end{array}$ & $\begin{array}{l}\text { elevated amount, builds } \\
\text { individual perceivability, } \\
\end{array}$ \\
& $\begin{array}{l}\text { and increases learning } \\
\text { about future favorable } \\
\text { circumstances; mingling }\end{array}$ \\
& power
\end{tabular}

Can upgrade or harm coach's notoriety, contingent upon how mentee behaves

\section{PSYCHOSOCIAL}

Friendship

Communal collaboration

Permits subordinate partner to believe like an consequence in shared associate

preference and

comprehension, with

charming casual trade about

work and nonworking

encounters

\author{
Senior partner can keep up \\ association with more \\ young parts of self and \\ expand association through \\ the coming era
}


Both people acquire a feeling

Confirmation of self from definite respect

passed on by the other
As senior associate

backing and consolation;

confronts maturing and essential faith is built up end-of-vocation matters, and, given an

establishment of the subordinating partner offers backing and acknowledgment, risk taking is heartened, taking into account testing with new practices gratefulness that empowers the senior to discover esteem in what he or she brings to the table

\begin{tabular}{llll}
\hline Counseling & $\begin{array}{l}\text { Empowers a person to } \\
\text { investigate individual matter } \\
\text { that may meddle with a } \\
\text { constructive feeling of self } \\
\text { and profession achievement }\end{array}$ & $\begin{array}{l}\text { Junior partner infers solace } \\
\text { in finding that questions } \\
\text { and issues can be shared }\end{array}$ & $\begin{array}{l}\text { Sharing bits of knowledge } \\
\text { empowers senior partner to } \\
\text { privately }\end{array}$ \\
& & $\begin{array}{l}\text { audit past purposes of } \\
\text { choice amid prior vocation } \\
\text { arranges and gives a } \\
\text { premise to feeling } \\
\end{array}$ \\
\end{tabular}

Role Modeling

\begin{abstract}
Senior partner's dispositions, qualities, and conduct give a model to the subordinating associate to imitate
\end{abstract}

\author{
Through discourse about \\ undertakings, regular \\ authoritative issues, and \\ vocation concerns, the \\ subordinates learn \\ methodologies, states of \\ mind, and principles \\ adhered by the model; \\ rethinks who he or she is \\ professionally
}

\section{Recognition and delegation} help senior partner see the worth in his or her own knowledge

Source: http://www.educause.edu (2016)

\section{Vital Elements of an Effective Mentoring Relationship}

According to a qualitative study conducted by Eller et al. (2013), they identified 8 themes portraying the vital elements of an effective mentoring relationship as shown in figure 1. These themes are granted in accordance of the recurrence of their presence in the workshop data the researchers conducted during this study: (i) mentees expressed that correspondence with mentors helps them pick up trust in their aptitudes and rouses them to build up their potential. They needed mentors who were "straightforward however not rude; (ii) mentees noticed the significance of "clear/exact objectives and anticipation," "objective setting and new opportunities" and mentors "increasing current standards to go past your own particular desires." Time was imperative in connection to objectives, with mentees taking note of the significance of "setting an appropriate pace" and "time management furthermore, 
adaptability."; (iii) mentees demonstrated that they needed mentors to "motivate critical thinking, innovativeness and certainty," and "strike a flash of enthusiasm for the understudy." There ought to be "shared and contagious energy and passion for work."; (iv) mentees distinguished the significance of "mutual friendship and a supportive relationship" "caring," and "nurturing." They ought to have a deep rooted relationship; (v) it was imperative to "regard, trust and appreciate each other." Having the same goal, running the same faith will lead to an outstanding team work; (vi) both mentees and mentors speculate that the mentoring relationship should produce research ability and understanding.

Mentors ought to "guarantee that understudies' abilities and learning develops," "transmit intelligence in fascinating ways," and "move forward our abilities." It was imperative to understudies that information picked up has a "genuine world association."; (vii) mentees and mentors trusted that it was critical to encourage both mentee freedom and cooperation. Mentee needed an "expanding awareness of accountability" and "to have chances to think autonomously and uniquely" "be a part of a group, with a significant role," and "make it group achievement."; (viii) mentees showed that they needed mentors to "lead by example," "model cooperation with others" and "share battles, memorable and present, to lessen the terrorizing variable."

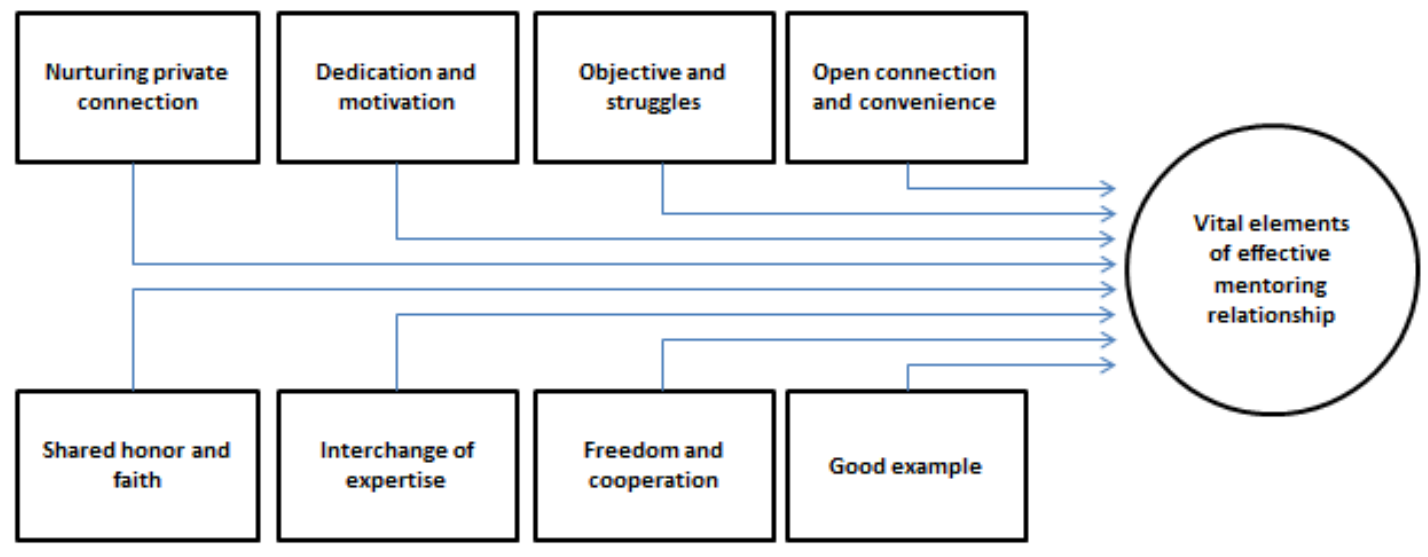

Figure 1. Vital elements of effective mentoring relationship

Source: Eller et al. (2013)

\section{Advantages of Mentorship in the Workplace}

Effective organizations abundant and minors utilize mentoring to handle complex human asset difficulties, like for instance, expanding worker retention and enhancing workforce profitability. Aside from that official mentoring is connected with the possibility to improve the capability of the high performing applicants, making them all around arranged to tackle administration parts in future. Subsequently, the expanded level of aptitudes of the work force serves as a method for upper hand for an association (Tansky and Cohen, 2001). Mentoring is a successful system to diminish the time it takes to share learning, competence or culture while keeping on advancing at the present pace of business. Workplace mentoring is a simple and powerful practice that can guide an organization become united, productive, more transparent, and highly competitive. Table 2 shows the top points of advantages of mentoring recorded from prior studies (Basheer, 2008; Tingum, 2016). 


\section{Macrothink}

International Journal of Human Resource Studies

ISSN 2162-3058

2017, Vol. 7, No. 4

Table 2. Advantages of mentorship in the workplace

\section{ADVANTAGES/BENEFITS}

As a mentee, you can likewise gain important business and life abilities from your mentor, including best business routines, suitable management and conventions. Mentors manage their mentee to pick up learning in definite industry information.

A frequently one of a kind advantage that must be picked up from a good mentor is a mix of definite industry information and individual acquaintances with the mentors contacts, which have regularly taken the mentor numerous years to build up, and which may not generally be promptly accessible to you.

An effective mentor can likewise mastermind encounters, for example, interest in attending work gatherings, meetings or work experience, which will empower you to get understanding into an association's way of life and frameworks, or how a particular part is performed in that association.

Talks with your mentor will extend your reasoning by furnishing you with another point of view to your own. Clarity in objectives is straightforwardly proportionate to the nature of work delivered. With this, the mentee can have self-inspiration to learn with certainty and test oneself to accomplish new objectives, learn new expertise and investigate choices.

Engaging work with a mentor also regularly makes a feeling of companionship that may not generally be accessible to you inside your association.

A competent mentor will give you profitable input or make proposals that will empower you to enhance your abilities or to experience self-improvement, eventually prompting your enhanced execution. Mentoring connections build worker engagement by offering space for discourse and normal input.

It will be an advantage for the mentee to listen to the lessons that your mentor has learned along the route through their past encounters - both their triumphs and disappointments. There is learning and information sharing incident.

Mentors frequently have the capacity to detect your novel abilities and make recommendations going to how you can assist create and take advantage of your gifts and abilities.

Having a good mentor will likewise empower you to test your thoughts and talk about your perspectives with an intrigued audience in a protected and classified environment. Information sharing is the cornerstone of a fruitful business, and it encourages both aptitude upgrade and persistent learning for representative.

After some time, an association can experience huge changes to its plan of action, workforce, and regular workplace. Solid mentoring connections can help workers climate these progressions and even develop from them. Representatives who are sure and secure in their work and their objectives welcome change and don't permit it to ruin their advancement. They are better prepared to face changes and adjust to them. 
Having a good mentor will serve as a preparation ground to empower you to grow in great mentoring practices and turn into a good mentor for others. A mentor chips away at both expert and self-improvement.

\section{Disadvantages of Mentorship}

In the past segment of this study we delineated what are seen as the possible advantages that may emerge as a result of cooperation in a mentoring program. In any case, the writing contains notices with respect to what Long (1997) has depicted as 'the dull side of mentoring'. Long has called attention to that at any rate a few analysts what's more, professionals are suspicious. Truth is told, under different circumstance the mentoring relationship can really be hindering to the guide, protégé or both. Murray and Owen (1991), in the same way as other different specialists, propose that the upsides of mentoring can be expanded profitability, cost viability, enhanced enlistment endeavors, expanded authoritative correspondence, inspiration of ranking staff and upgrades in vital and progression arranging. Several studies was made in identifying the disadvantages of mentorship but two of the most exhaustive synopses in regards to the 'dull side of mentoring have been delivered by Douglas (1997). Each of these is currently quickly recorded.

Long (1997) depicts thirteen possible matter with respect to mentoring. These worries are distinguished as coaching is tedious for all the involve personnel, lack of common sense of the coaching process, failed coordination of guides and protégés, absence of comprehension of the coaching procedure, possible creation of work strains, couple of accessible guides particularly ladies, over utilization of accessible coaches, absence of access to tutoring for ladies and minority bunches, generation of the coach's work style, poor relationship amongst tutor and mentee, high deceivability of coaching system absence of clarity as to whether tutoring is connected to professional success and lacking subsidizing or end of financing before the project can show potential advantages (Ehrich et al., 1999). In Table 3, Douglas (1997) outlined the probable downsides of mentoring relationship.

Table 3. Downside of mentoring method

\begin{tabular}{lll}
\hline ASSOCIATION & MENTEE/PROTÉGÉ & MENTOR \\
\hline $\begin{array}{l}\text { Establishing an Atmosphere of } \\
\text { Reliance }\end{array}$ & Unfavorable Encounters & $\begin{array}{l}\text { Inadequate Recognized } \\
\text { Advantages }\end{array}$ \\
\hline Absence of Hierarchical Approval & Disregard of Core Occupation & Time Shortage \\
\hline $\begin{array}{l}\text { Expenses and Assets connected } \\
\text { with Supervising and Managing } \\
\text { projects }\end{array}$ & $\begin{array}{l}\text { Function strife amidst Supervisor } \\
\text { and mentor }\end{array}$ & Exasperation of Mentees \\
\hline $\begin{array}{l}\text { Challenges in Planning Programs } \\
\text { with Hierarchical Activities }\end{array}$ & Unreasonable Encounters Over & $\begin{array}{l}\text { Inadequate Knowledge required } \\
\text { for Mentoring Function }\end{array}$ \\
& Reliance on the Tutoring & \\
& relationship & Constrain to Accept the Mentoring \\
\end{tabular}

Source: Mentoring: Pros and cons for HRM, Ehrich and Hansford (1999) 


\section{Link between Mentoring and Profession Achievement}

Our motivation in directing the present conceptual paper was to abridge existing information concerning the relationship amongst tutoring and advantages for protégé's. The study also meant to decide the connection of formal mentoring and informal mentoring arranged with profession achievement; and the function of mentoring procurement in the settled relationship of formal and informal mentoring acquired with profession achievement. Mentoring was identified with profession achievement, vocation anticipation, vocation fulfillment, profession obligation, and the extent of acquired mentoring. These discoveries were in accordance with a portion of prior exploration (Allen et al., 2006). Hence, the current research provided headings to the solidification of proof that having been mentored improves the probability of turning into a coach, and that turning into a coach yields unmistakable advantages for one's vocation. The previous emphasizes the significance of giving casual coaching as an approach to develop a mentoring society in the association (Leavitt, 2011).

The recent reveals that turning into a guide advantages one's own particular vocation from a subjective (i.e. individual delight) point of view. To add up, the mentored versus non-mentored outcome uncovered solid impacts for profession particular variables like, vocation responsibility, desire for progression, and vocation fulfillment. These outcomes recommend that the steadiest advantages of mentoring might be the effect on emotional responses to the work environment and positive mental sentiments with respect to one's profession. Improved profession expectation can go about as a solid motivation to wind up a mentor in the present period in which expanded work weight and lessened vocation assurance go about as discouragement powers for administrators and management to commit time for the improvement of less senior authoritative individuals.

Additional proposal of the discoveries is that giving and getting coaching make reciprocal commitments to profession achievements and anticipation. The useful ramifications is that getting mentoring keeps on being vital for vocation advancement notwithstanding when people have achieved authoritative positions that permit them to be mentor. So as we hypothesized, the outcomes give some confirmation that target profession achievement pointers, for example, remuneration and advancement, are more exceptionally identified with profession coaching than to psychosocial tutoring. The outcomes are not astonishing while considering the diverse practices connected with profession versus psychosocial tutoring. It was additionally noticed that the impact sizes for the target vocation pointers were more grounded when looking at coached versus non-mentored bunches than while analyzing the relationship between mentoring capacities gave and objective vocation advantages. Additionally, the analysts have started this examination paper with the idea that the advantages of having a mentor have gotten plentiful consideration (Dreher and Ash, 1990; Godshalk and Sosik, 2003; Lankau and Scandura, 2002; Ragins et al., 2000; Scandura, 1992; Scandura and Schriesheim, 1994).

In like manner, one critical essential target of the current study was that there is a definite connection between formal coaching, informal coaching and vocation achievement. Presently, formal coaching (vocation related) and informal mentoring (socio-passionate) if 
commitments to profession achievement. This result recommends that the advantages for the professions of mentors are predominantly collected by the vocation related elements of coaching and socio-passionate elements of tutoring. Along these lines, it can be likely inferred that experimental confirmation is amassing towards the way that in formal tutoring connections it is transcendently vocation related tutoring that is connected with vocation results for coaches furthermore casual coaching connections it is prevalently socio-passionate coaching capacities assume as a noteworthy part.

\section{Conclusion}

The discoveries of this research show that a mentoring program goes about as a successful foreseeing variable of individual progression in the authoritative example. This outcome has bolstered past studies and developed mentoring study writing for the most part distributed in Western authoritative settings. Along these lines, present study and training inside tutoring program, mentors requires to acknowledge mentoring class as a crucial part of hierarchical coaching program where legitimately actualized informal and formal mentoring exercises may emphatically expand positive consecutive attitudinal and behavioral results (e.g., vocation improvement, psychosocial bolster, work fulfillment, representative obligation, work execution, trust, and morals). Despite the fact that strikingly, our outcomes propose that coaching is more firmly identified with protégé attitudes than to behavior, and career outcomes. It might be that states of mind are more susceptible to change than are results that are all the more logically needy or more affected by stable individual variables. Obviously if the mentor is efficient enough to pursue the mentee backed up with the right knowledge and determination positive output is absolute.

In this manner, these positive results may prompt maintained and bolstered hierarchical key vision and mission. In whole, this research has demonstrated that the presence of mentoring projects have been decidedly connected to vocation improvement and psychosocial support of the workers in the inspected association. Mentoring also appears to be vital to keep on examining the relationship between profession achievements and mentoring others. We trust the present results plays as a starting point for such research. By concentrating on the mentor, the current research gives an all the more full-range comprehension of the results that may be connected with mentorships. This study might be helpful to associations that need to urge people to expect the tedious and testing errand of coaching other.

\section{References}

Allen, T. D., \& Eby, L. T. (2003). Relationship effectiveness for mentors: Factors associated with Learning and Quality. Journal of Management, 29(4), 469-486. https://doi.org/10.1016/S0149-2063(03)00021-7

Allen, T. D., Eby, L. T., Poteet, M. L., Lentz, E. \& Lima, L. (2004). Career benefits associated with mentoring for protégés: a meta-analysis. Journal of Applied Psychology, 89(1), 127-136. https://doi.org/10.1037/0021-9010.89.1.127

Allen, T. D., Eby, L. T. \& Lentz, E. (2006). Mentor and protégé outcomes associated with formal mentoring programs: Closing the gap between research and practice. Journal of 
Applied Psychology, 91(3), 567-578. https://doi.org/10.1037/0021-9010.91.3.567

Allen, T. D., Eby, L. T., O’Brien, K. E. \& Lentz, E. (2008). The state of mentoring research: a qualitative review of current research methods and future research implications. Journal of Vocational Behavior, 73(3), 343-357. https://doi.org/10.1016/j.jvb.2007.08.004

Aryee, S., Lo, S. \& Kang, I. L. (1999). Antecedents of early career stage mentoring among Chinese employees. Journal of Organizational Behavior, 20(5), 563-576. http://www.jstor.org/stable/3100429

Ayres, H. (2006). Career development in tourism and leisure: an exploratory study of the influence of mobility and mentoring. Journal of Hospitality Tourism Manage, 13(2), 113-123. https://doi.org/10.1375/jhtm.13.2.113.

Bahniuk, M. H. \& Hill, S. K. (1998). Promoting career success through mentoring. Review of Business, 19(3), 4-7.

Basheer, T. (2008) 10 Benefits of Having Good Mentors. Ezine Issues, 4(1), 1-2. https://www.blueskycoaching.com.au/pdf/v4i10_mentor.pdf

Buell, C. (2004). Models of Mentoring in Communication. Journal of Communication Education, 53(1), 56-73. https://doi.org/10.1080/0363452032000135779

Cho, C. S., Ramanan, R. A. \& Fieldman, M. D. (2011). Defining the Ideal Qualities of Mentorship: A Qualitative Analysis of the Characteristics of Outstanding Mentors. The American Journal of Medicine, 124(5), 453-458. https://doi.org/10.1016/j.amjmed.2010.12.007

Douglas, C. A. (1997). Formal mentoring programs in organizations: an annotated bibliography. Greensboro: Centre for Creative Leadership.

Dreher, G. F., \& Ash, R. A. (1990). A comparative study of mentoring among men and women in managerial, professional, and technical positions. Journal of Applied Psychology, 75(5), 539-546. https://doi.org/10.1037/0021-9010.75.5.539

Eby, L. T., McManus, S. E., Simon, S. A., \& Russell, J. E. (2000). The protégé's perspective regarding negative mentoring experiences: the development of taxonomy. Journal of Vocational Behavior, 57, 1-21. https://dx.doi:10.1006/jvbe.1999.1726

Ehrich, L. C. \& Hansford, B. (1999). Mentoring: Pros and cons for HRM. Asia Pacific Journal of Human Resources, 37(3), 92-107. https://doi.org/10.1177/103841119903700307

Eller, L. S., Lev, E. L. \& Feurer, A. (2013). Key components of an effective mentoring relationship: A qualitative study. Journal of Nurse Education Today, 34(5), 815-820. https://doi.org/10.1016/j.nedt.2013.07.020

Fagenson, E.A., (1992). Mentoring: who needs it? A comparison of protégés' and non-protégé needs for power, achievement, affiliation, and autonomy. Journal of Vocational Behavior, 41(1), 48-60. https://doi.org/10.1016/0001-8791(92)90038-2. 
Godshalk, V. M. \& Sosik, J. J. (2003). Aiming for career success: The role of learning goal orientation in mentoring relationship. Journal of Vocational Behavior, 63(3), 417-437. https://doi.org/10.1016/S0001-8791(02)00038-6.

Graen, G. B. \& Uhl-Bien, M. (1995). Relationship-based approach to leadership: development of leader-member exchange (LMX) theory of leadership over 25 years: Applying a multi-level multi-domain perspective. The Leadership Quarterly, 6(2), 219-247. https://doi.org/10.1016/1048-9843(95)90036-5.

Haggard, D. L., Dougherty, T. W., Turban, D. B. \& Wilbanks, J. E. (2011). Who is a mentor? A review of evolving definitions and implications for research. Journal of Management, 37(1), 280-304. https://doi.org/10.1177/0149206310386227.

Hoffmann, M. \& Loughead, T. (2016). A comparison of well-peer mentored and non-peer mentored athletes' perceptions of satisfaction. Journal of Sports Sciences, 34(5), 450-458. https://doi.org/10.1080/02640414.2015.1057517

Kim, S. S., Im, J. \& Hwang J. (2015). The effects of mentoring on role stress, job attitude, and turnover intention in the hotel industry. International Journal of Hospitality Management, 48, 68-82. https://doi.org/10.1016/j.ijhm.2015.04.006

Kim, B., Lee, G. \& Carlson, K. (2010). An examination of the nature of the relation-ship between Leader-Member-Exchange (LMX) and turnover intent at different organizational levels. International Journal of Hospitality Management, 29(4), 591-597. https://doi.org/10.1016/j.ijhm.2009.10.025

Kram, K. E. (1985). Mentoring at Work: Developmental Relationships in Organizational Life. Human Resource Management, 25(4), 639-644. https://doi.org/10.1002/hrm.3930250410

Lankau, M. J. \& Scandura, T. A. (2002). An investigation of personal learning in mentoring relationships: content, antecedents, and consequences. The Academy of Management Journal, 45(4), 779-790. http://www.jstor.org/stable/3069311

Lankaua, M. J., Carlson, D. S. \& Nielsonc, T. R. (2006). The mediating influence of role stressors in the relationship between mentoring and job attitudes. Journal of Vocational Behavior, 68(2), 308-322. https://doi.org/10.1016/j.jvb.2005.06.001

Leavitt, C. (2011). Developing Leaders through Mentoring: A Brief Literature Review. Columbus, OH: ERIC. https://eric.ed.gov/?id=ED517965

Long, J. (1997). The dark side of mentoring. Australian Educational Research, 24(2), 115-83. http://www.aare.edu.au/publications-database.php/1152/the-dark-side-of-mentoring

Mullen, E. J. \& Noe, R. A. (1999). The mentoring information exchange: when do mentors seek information from their protégés? Journal of Organizational Behavior, 20(2), 233-242. http://www.jstor.org/stable/3100423

Murray, M. \& Owen, M. A. (1991). Beyond the Myths and Magic of Mentoring: How to facilitate an effective mentoring program. Asia Pacific Journal of Human Resources, 31(1), 
108-109. https://doi.org/10.1177/103841119303100114

Noe, R. A. (1988). An investigation of the determinants of successful assigned mentoring $\begin{array}{llll}\text { relationships. Personnel } & \text { Psychology, } & \text { 41(3), }\end{array}$ https://doi.org/10.1111/j.1744-6570.1988.tb00638.x

Patwardhan, V., \& Venkatachalam, V. D. (2012). A study on career management issues of women managers in Indian Hospitality Industry. In: International Conference on Information Technology, 4-5th Nov 2011, Dehradun.

Ragins, B. R., \& Kram, K. E. (2007). The Handbook of Mentoring at Work Theory, Research and Practice. Sage Publications, Inc.: Los Angeles.

Ragins, B. R., Cotton, J. L., \& Miller, J. S. (2000). Marginal mentoring: the effects of type of mentor, quality of relationship, and program design on work and career attitudes. Academy of Management Journal, 43(6), 1177-1194. https://doi.org/10.2307/1556344

Reid, M. F., Allen, M. W., Riemenschneider, C. K., \& Armstrong, D. J. (2008). The role of mentoring and supervisor for state IT employees' affective organizational commitment. Review of Public Personnel Administration, 28(1), 60-78. https://doi.org/10.1177/0734371X07311703

Rhodes, J. E. (2005). A model of youth mentoring. In: DuBois, DL.; Karcher, MJ., editors. Handbook of youth mentoring. Thousand Oaks, CA: Sage.

Scandura, T., A., \& Schriesheim, C. A. (1994). Leader-member exchange and supervisor career mentoring as complementary constructs in leadership research. The Academy of Management Journal, 37(6), 1588-1602. http://www.jstor.org/stable/256800

Scandura, T. A. (1992). Mentorship and career mobility: an empirical investigation. Journal of Organizational Behavior, 13(2), 169-174. https://doi.org/10.1002/job.4030130206

Scandura, T. A., \& Ragins, B. R. (1993). The effects of sex and gender role orientation on mentorship in male-dominated occupations. Journal of Vocational Behavior, 43(3), 251-265. https://doi.org/10.1006/jvbe.1993.1046

Schyns, B., \& Croon, M. A. (2006). A model of task demands, social structure, and leader-member exchange and their relationship to job satisfaction. International Journal of Human Resource Management, 17(4), 602-615. https://doi.org/10.1080/09585190600581378

Tansky, J. W., \& Cohen, D. J. (2001). The relationship between organizational support, employee development, and organizational commitment: An empirical study. Human Resource Development Quarterly, 12(3), 285-300. https://doi.org/10.1002/hrdq.15

Tingnum J. (2016). The Advantages of Mentoring in the Workplace. Available at http://smallbusiness.chron.com/advantages-mentoring-workplace-18437.html

Turban, D. B. \& Dougherty, T. W. (1994). Role of Protégé Personality In Receipt Of Mentoring And Career Success. The Academy of Management Journal, 37(3), 688-702. 
http://www.jstor.org/stable/256706

Viator, R. E. (2001). The association of formal and informal public accounting mentoring with role stress and related job outcomes. Accounting, Organizations and Society, 26(1), 73-93. https://doi.org/10.1016/S0361-3682(00)00002-7

\section{Copyright Disclaimer}

Copyright for this article is retained by the author(s), with first publication rights granted to the journal.

This is an open-access article distributed under the terms and conditions of the Creative Commons Attribution license (http://creativecommons.org/licenses/by/4.0/). 